\title{
Mass-flowering crops enhance wild bee abundance
}

\author{
Andrea Holzschuh • Carsten F. Dormann • \\ Teja Tscharntke $\cdot$ Ingolf Steffan-Dewenter
}

Received: 27 March 2012/ Accepted: 11 October 2012/Published online: 1 November 2012

(C) The Author(s) 2012. This article is published with open access at Springerlink.com

\begin{abstract}
Although agricultural habitats can provide enormous amounts of food resources for pollinator species, links between agricultural and (semi-)natural habitats through dispersal and foraging movements have hardly been studied. In 67 study sites, we assessed the interactions between mass-flowering oilseed rape fields and semi-natural grasslands at different spatial scales, and their effects on the number of brood cells of a solitary cavity-nesting bee. The probability that the bee Osmia bicornis colonized trap nests in oilseed rape fields increased from 12 to $59 \%$ when grassland was nearby, compared to fields isolated from grassland. In grasslands, the number of brood cells of O. bicornis in trap nests was $55 \%$ higher when adjacent to oilseed rape compared to isolated grasslands. The percentage of oilseed rape pollen in the larval food was higher in oilseed rape fields and grasslands adjacent to oilseed rape than in isolated grasslands. In both oilseed rape fields and grasslands, the number of brood cells was positively
\end{abstract}

Communicated by Riccardo Bommarco.

Electronic supplementary material The online version of this article (doi:10.1007/s00442-012-2515-5) contains supplementary material, which is available to authorized users.

A. Holzschuh $(\bowtie) \cdot$ I. Steffan-Dewenter Department of Animal Ecology and Tropical Biology,

Biocenter, University of Würzburg, Am Hubland, 97074 Würzburg, Germany

e-mail: andrea.holzschuh@uni-wuerzburg.de

A. Holzschuh · T. Tscharntke

Agroecology, Georg-August University,

Grisebachstr. 6, 37077 Göttingen, Germany

C. F. Dormann

Biometry and Environmental System Analysis, University

of Freiburg, Tennenbacher Str. 4, 79106 Freiburg, Germany correlated with the percentage of oilseed rape pollen in the larval food. We show that mass-flowering agricultural habitats - even when they are intensively managed - can strongly enhance the abundance of a solitary bee species nesting in nearby semi-natural habitats. Our results suggest that positive effects of agricultural habitats have been underestimated and might be very common (at least) for generalist species in landscapes consisting of a mixture of agricultural and semi-natural habitats. These effects might also have-so far overlooked-implications for interspecific competition and mutualistic interactions in semi-natural habitats.

Keywords Canola $\cdot$ Oilseed rape $\cdot$ Pollen $\cdot$ Spillover . Trap nests

\section{Introduction}

Intensive agriculture has caused alarming declines in farmland biodiversity (Krebs et al. 1999). One of the main reasons for the negative effects of agriculture is the expansion of agricultural land at the cost of semi-natural and natural habitats (henceforth termed natural habitats). However, intensively used agricultural landscapes often provide resources even for species that depend on natural habitat at least temporally during their life cycle (Dunning et al. 1992). Many of these species are responsible for important ecosystem services such as biocontrol and pollination in both agricultural and natural habitats (Aguilar et al. 2006; Rand and Louda 2006; Klein et al. 2007; Letourneau et al. 2009). The presence of species in agricultural habitats may indicate a benefit from resources provided there. While cross-habitat spillover from natural habitats on agricultural habitats has been relatively well 
documented, there is a general lack of studies addressing effects of agricultural on natural habitats (Blitzer et al. 2012)

Managed habitats often surpass natural habitats in the amount of food resources they offer, such as plant biomass attracting herbivores and subsequently their predators (Rand et al. 2006), or the amount of pollen- and nectar-attracting pollinators (Morandin and Winston 2005; Carvalheiro et al. 2011). Mass-flowering oilseed rape fields provide 350,000-700,000 plants per hectare, each producing more than 100 flowers (Hoyle et al. 2007) during a flowering period of about 4 weeks. Because of the enormous food density and the easy accessibility of nectar and pollen, foraging on mass-flowering crops like oilseed rape may pay off for wild bees from nearby natural habitats, despite having to fly back to their nesting sites after every foraging trip.

Besides the decline of nesting sites, which are almost exclusively found in natural habitats, the decline of food resources is supposed to be the major threat of wild bees in many regions worldwide (Holzschuh et al. 2008; SteffanDewenter and Schiele 2008; Potts et al. 2010). While, up to now, most research has focused on the negative effects of increased cover of agricultural land and the simultaneous decrease in natural habitats (e.g., Ricketts et al. 2008; Garibaldi et al. 2011), potential resource support from agricultural land for populations in natural habitats has been disregarded (Rand et al. 2006; Blitzer et al. 2012). Cross-habitat fluxes of individuals and food resources from agricultural land to natural habitats can be expected to have often substantial consequences for the fitness of individuals reproducing in natural habitats, and subsequently for population dynamics, species interactions and ecosystem services in both natural and agricultural habitats (Diekötter et al. 2010; Gladbach et al. 2011; Holzschuh et al. 2011; Jauker et al. 2012).

The area cultivated with mass-flowering oilseeds in Europe has increased by $49.9 \%$ between 2000 and 2010 (European Commission 2011), largely due to an increased demand for biofuel during the last decade. However, the impact of oilseed rape on solitary wild bees has so far hardly been studied. Related studies from social bumblebees that were conducted several weeks after the flowering period of oilseed rape showed positive effects of oilseed rape on abundances of short-tongued bumblebees (Westphal et al. 2006; Diekötter et al. 2010), mixed effects on abundances of long-tongued bumblebees (Westphal et al. 2006; Diekötter et al. 2010), and no effects on the percentage of colonies producing sexual offspring (Westphal et al. 2009). Studies on solitary bees show that high amounts of oilseed rape at the landscape scale have positive effects on a solitary bee nesting in semi-natural habitats (Jauker et al. 2012), and suggest that flowering oilseed rape can counteract negative effects of low wild flower densities in nearby semi-natural habitats
(Holzschuh et al. 2011). Jauker et al. (2012) proposed as a possible explanation for these positive effects that bees benefit from the abundant nectar provided by oilseed rape, and claimed the equally abundant pollen supply not to be important. However, a study on the impact of oilseed rape pollen on the abundance of bees nesting in semi-natural habitats is so far lacking.

In our study, we focused on the impact of oilseed rape on the abundance of the solitary and polylectic Red Mason Bee Osmia bicornis L. (Megachilidae), which nests in cavities in natural and semi-natural habitats. In 67 study sites, we assessed the effects of oilseed rape on bees in semi-natural grasslands and vice versa at the local scale (habitat types directly adjoining vs. isolated habitats) and at the landscape scale (low to high proportions of oilseed rape or semi-natural habitats). In artificial nests, we evaluated the number of brood cells and the percentage oilseed rape pollen in larval food as well as the relationship between the percentage oilseed rape pollen and the number of brood cells.

We hypothesized that

1. without nearby source habitat, $O$. bicornis will not nest in oilseed rape fields; i.e., the occurrence of $O$. bicornis in trap nests in oilseed rape fields increases when grassland adjoins;

2. O. bicornis profits from mass-flowering oilseed rape; i.e., the number of $O$. bicornis brood cells in trap nests in grasslands adjacent to oilseed rape is higher than in isolated nesting aids and increases with the proportion of oilseed rape in the landscape;

3. the percentage oilseed rape pollen in larval food increases with local availability (highest in oilseed rape fields, intermediate in grasslands adjacent to oilseed rape and lowest in grasslands isolated from oilseed rape and with landscape-scale availability of oilseed rape pollen (i.e. proportion of oilseed rape fields in the landscape);

4. oilseed rape pollen contributes substantially to offspring provisioning by $O$. bicornis, leading to increases in the number of brood cells with increasing percentage of oilseed rape pollen in larval food; additionally, the positive impact of oilseed rape pollen should decrease with increasing availability of alternative food resources at the local and landscape scale.

\section{Materials and methods}

Study sites

The study was carried out in 2007 near the city of Göttingen $\left(51.5^{\circ} \mathrm{N}, 9.9^{\circ} \mathrm{E}\right)$, Lower Saxony, Germany. In an 
area of about $25 \times 30 \mathrm{~km}$, we selected 67 study sites (33 calcareous grasslands and 34 oilseed rape fields belonging to four categories (ESM 1): (1) 16 grasslands were isolated by at least $230 \mathrm{~m}$ from the nearest oilseed rape field (mean distance from grassland to field edge $\pm \mathrm{SE}: 481 \pm 8.8 \mathrm{~m}$ ); (2) 17 grasslands were within 1-15 $\mathrm{m}$ distance of oilseed rape; (3) 17 oilseed rape fields were within 1-15 $\mathrm{m}$ distance of the study grasslands; and (4) 17 oilseed rape fields were isolated by at least $570 \mathrm{~m}$ from calcareous grasslands (mean distance \pm SE: $1,598 \pm 59.7 \mathrm{~m}$; ESM 2). Each of the 17 study grasslands of category 2 was in $1-15 \mathrm{~m}$ distance of one of the studied oilseed rape fields of category 3 . Study grasslands and oilseed rape fields were at least $1 \mathrm{~km}$ apart from other study grasslands and oilseed rape fields, respectively. At $300 \mathrm{~m}$ distance from calcareous grassland, abundances of cavity-nesting bees have been shown to be reduced by $95 \%$ compared to grasslands (Krewenka et al. 2011). All study sites where we recorded Osmia bicornis in our traps were included in the analyses of pollen contents and brood cell numbers (in all cases $>9$ brood cells per site): (1) 14 grasslands isolated from oilseed rape; (2) 12 grasslands adjacent to oilseed rape; and (3) 10 oilseed rape fields adjacent to grasslands. Category 4 (oilseed rape fields isolated from grasslands) was excluded from the analyses of pollen contents and brood cell numbers because only 2 sites had been colonized by $O$. bicornis. Instead, the 34 oilseed rape fields of category 3 and 4 were included in an analysis of $O$. bicornis incidence (see below).

Oilseed rape fields were sown with Brassica napus in the autumn of the previous year and were conventionally managed with usually one insecticide application during the flowering period. Isolated grasslands and grasslands adjacent to oilseed rape were similar in management, exposition, inclination and size (grasslands isolated from oilseed rape: mean size \pm SE: $1.7 \pm 0.3$ ha, $\min : 0.2$ ha, $\max : 6.8$ ha; grasslands adjacent to oilseed rape: mean size $\pm \mathrm{SE}$ : $1.7 \pm 0.5$ ha, min: 0.1 ha, $\max : 4.8$ ha). Flower cover (\% cover of flower corollas per area ground surface) and the number of plant species flowering were recorded once during oilseed rape flowering in a 0.1 -ha plot per grassland, and did not significantly differ (all $P>0.12$ ) between grasslands isolated from oilseed rape (flower cover: $0.10 \pm 0.07 \%$, min: $0.0001 \%$, $\max : 1.0 \%$; species number: $4.07 \pm 0.58$, min: 1, max: 9) and grasslands adjacent to oilseed rape (flower cover: $0.46 \pm 0.17 \%$, $\min : 0.0001 \%$, $\max$ : $2.12 \%$; species number: $4.58 \pm 0.51$, $\min : 3$, $\max : 7)$.

Around each study site, oilseed rape fields and seminatural habitats (calcareous grasslands, orchard meadows, old fallows, hedgerows) were mapped in landscape circles with radii of $250,500,750$, and $1,000 \mathrm{~m}$. The proportions of oilseed rape fields in the landscape circles were calculated with GIS software (ESRI ArcView 3.2). The proportion of oilseed rape spanned a gradient from 0 to 65,29 ,
23 , and $17 \%$ in the $250,500,750$, and $1,000 \mathrm{~m}$ radius, respectively, and was not correlated with any other habitat type (Spearman rank correlations, all $P>0.1, n=34$ ), but was highly negatively correlated with the distance to the next oilseed rape field at all scales (Spearman rank correlations, all $P<0.001, n=34)$. The proportion of seminatural habitats spanned a gradient from 0.3 to $43,26,15$, and $13 \%$, respectively, and was positively correlated with the Shannon Index of habitat diversity in landscape circles with 750 and 1,000 $\mathrm{m}$ radius (Spearman rank correlations, all $P<0.01, n=33$ ).

\section{Pollen and brood cells in trap nests}

We established trap nests in the edge and the center of our 67 study sites to assess the effect of oilseed rape on pollencollecting behavior and the number of brood cells of O. bicornis. This solitary, polylectic bee can nest in a variety of naturally pre-existing cavities and also colonizes artificial trap nests. $O$. bicornis is the most abundant cavitynesting bee in the study area (Holzschuh et al. 2010). Between April and June, females of $O$. bicornis build nests with up to 30 brood cells (Westrich 1989) and collect pollen for larval provisioning nearby their nests within a radius of up to $600 \mathrm{~m}$ (Gathmann and Tscharntke 2002). A high number of brood cells per trap nest can reflect both a preference of females to nest at this specific location and a high reproductive output per female.

Trap nests consisted of four plastic tubes $(20 \mathrm{~cm}$ long, $10.5 \mathrm{~cm}$ diameter), each filled with about 200 internodes (20 cm long) of common reed Phragmites australis (see Tscharntke et al. 1998) and fixed on a post at a height of $1.2 \mathrm{~m}$. Internodes which contain brood cells of $O$. bicornis can be easily recognised by a clay cap, which the bee builds at the end of the internode. One female can occupy more than one internode. We placed trap nests in the centre and the edge of the 67 study sites (134 trap nests with 536 plastic tubes). In oilseed rape fields, edge trap nests were placed between the first and the second row of oilseed rape plants, center trap nests were placed at $20 \mathrm{~m}$ distance from the edge. In grasslands, edge trap nests were placed at $1 \mathrm{~m}$ distance from the habitat border and center trap nests were placed at $20 \mathrm{~m}$ distance from the edge trap nests. Trap nests were established in March and checked for O. bicornis nests at the beginning of oilseed rape flowering in April. No nests had been built by O.bicornis before the beginning of oilseed rape flowering. Directly after the end of oilseed rape flowering (26 days later in May), all reed internodes containing bee brood cells were collected, stored at $4{ }^{\circ} \mathrm{C}$ to stop larval development, and opened in the laboratory. The number of $O$. bicornis brood cells per trap was recorded (Tscharntke et al. 1998). 
For the identification of forage plants, pollen was collected from the first and the last brood cell per reed internode. These two most separated brood cells within a reed internode are normally built with an interval of several days inbetween (Westrich 1989) and might thus mirror the pollen-collection behavior at two different time points during oilseed rape flowering. All brood cells of $O$. bicornis contained large amounts of pollen, because larval development had not made considerable progress by that time. After transferring a small sample of the pollen from the brood cell to a glass slide, the percentage pollen of Brassicaceae was determined under a light microscope for 300 pollen grains, which were located in a randomly chosen cluster within the sample. We assume that all pollen of the Brassicaceae pollen came from oilseed rape, because no other Brassicaceae were abundantly flowering at that time in grasslands, crop fields, or field margin strips. Pollen analyses were conducted on 843 brood cells from the 36 sites where $O$. bicornis occurred. The numbers of brood cells were summed over the four plastic tubes of a trap nest per post and the two trap nests per site, and the percentage oilseed rape pollen per brood cell was averaged over all brood cells of a site, because the position of the trap nests in the field neither affected the number of brood cells ( $t$ test; $\left.F_{1,55}=1.3, P=0.25\right)$ nor the percentage oilseed rape pollen ( $t$ test; $F_{1,55}=1.4, P=0.24$ ).

\section{Statistical analyses}

The effect of grassland on the incidence (presence or absence) of $O$. bicornis in oilseed rape was assessed in a generalized linear model with quasibinomial errors and the predictor presence of adjacent grassland (oilseed rape adjacent to grassland vs. oilseed rape isolated from grassland).

To assess whether the number of $O$. bicornis brood cells in grasslands is higher adjacent to oilseed rape than isolated from oilseed rape and increases with the proportion of oilseed rape in the landscape, we performed ANCOVAs (type I sums of squares) with the dependent variable number of $O$. bicornis brood cells per grassland and the predictors presence of adjacent oilseed rape (grassland adjacent to oilseed rape vs. grassland isolated from oilseed rape), proportion of oilseed rape in the surrounding landscape circle and their interaction. Separate models were calculated for the different landscape circles (250, 500, $750,1,000 \mathrm{~m}$ radius).

The effects of local and landscape-scale availability of oilseed rape pollen on the percentage oilseed rape pollen in larval food were assessed in ANCOVAs with percentage oilseed rape pollen as the dependent variable and the predictor site type (oilseed rape adjacent to grassland vs. grassland adjacent to oilseed rape vs. grassland isolated from oilseed rape) and their interaction. Separate models were calculated for the different landscape circles (250, $500,750,1,000 \mathrm{~m}$ radius). In the pollen models, we considered the 36 sites where trap nests had been colonized by O. bicornis. These were 14 of the 16 sites of category 1 (grasslands isolated from oilseed rape) and 22 of 34 sites of categories 2 and 3 (grasslands adjacent to oilseed rape and oilseed rape adjacent to grassland). All colonized sites of category 1 and eight colonized sites of categories 2 and 3 were spatially separated from all other sites; in seven cases, the two sites of categories 2 and 3 were directly adjacent to each other. For these seven cases, we additionally conducted a $t$ test for paired samples (sites of category 2 vs. 3 ) and compared the result to the result of the ANCOVA to check whether neglecting the partly nested structure of the model affected the outcome of the ANCOVA model. Furthermore, we assessed-for grasslands isolated from oilseed rape-the relationship between percentage oilseed rape pollen in larval food and the distance from the nearest oilseed rape field in a linear regression model.

To assess whether the number of $O$. bicornis brood cells increased with increasing percentage of oilseed rape pollen in larval food, we calculated linear regression models with the dependent variable number of brood cells per site and the predictor percentage of oilseed rape pollen in larval food. Again, we considered those 36 sites where trap nests had been colonized by $O$. bicornis. The hypothesis that the positive impact of oilseed rape pollen decreases with increasing availability of alternative food resources at the local and landscape scale was tested in separate linear regression models for grasslands and oilseed rape fields with the dependent variable number of brood cells per site, the predictors percentage of oilseed rape pollen, proportion of semi-natural habitats in the surrounding landscape circle, flower cover, and diversity of flowering plants in the grassland (or in the adjacent grassland in case of oilseed rape fields), and the two-fold interactions between percentage oilseed rape pollen and the other predictors. Separate models were calculated for the four landscape circles. All models were computed in R (v.2.11.1; R Development Core Team 2011). Maximal models were simplified in a manual stepwise backward selection on the basis of $F$ tests (Crawley 2007). Predictors with $p>0.05$ were removed from the maximal models. Tukey's post hoc test for multiple comparisons of means were performed with heteroscedastic consistent covariance estimation, which is a robust method for comparing means of groups with unbalanced group sizes (Herberich et al. 2010; packages multcomp and sandwich).

\section{Results}

We recorded 2,473 brood cells in nests of Osmia bicornis, 1,104 brood cells in 12 grasslands adjacent to oilseed rape, 
715 brood cells in 14 grasslands isolated from oilseed rape, 606 brood cells in 10 oilseed rape fields adjacent to grasslands, and 48 brood cells in 2 oilseed rape fields isolated from grassland. Trap nests were not colonized by O. bicornis in 8 of 34 grasslands and 22 of 34 oilseed rape fields.

The presence of adjacent grassland had a positive effect on the number of brood cells in oilseed rape resulting in 606 brood cells in nests of the O. bicornis in 10 of 17 oilseed rape fields adjacent to grassland (59\% of the fields), but only 48 brood cells in 2 of 17 oilseed rape fields isolated from grassland (12\% of the fields; GLM with quasibinomial errors: $F_{1,32}=8.3, P=0.007$; Fig. 1a). The presence of adjacent oilseed rape had a positive effect on the number of brood cells in grasslands. The mean number of brood cells per site was $55 \%$ higher in grasslands adjacent to oilseed rape than in isolated grasslands (Fig. $1 \mathrm{~b} ; R^{2}=0.16, F_{1,24}=4.6, P=0.041$ ), but was not affected by the proportion of oilseed rape in the landscape at any of the four spatial scales.

The percentage oilseed rape pollen in larval food was higher in oilseed rape fields $(t=4.0, P<0.001)$ and in grasslands adjacent to oilseed rape $(t=4.1, P<0.001)$ than in grasslands isolated from oilseed rape, but did not differ between grasslands adjacent to oilseed rape and oilseed rape fields ( $t=0.7, P>0.7$; Fig. 2) and was not affected by the proportion of oilseed rape in the landscape at any of the four spatial scales. Grasslands adjacent to oilseed rape did not differ from directly adjacent oilseed rape fields when analysed in a $t$ test for paired samples $(t=0.23, P>0.8)$. The percentage oilseed rape pollen was not related to the distance from the nearest oilseed rape fields in grasslands isolated from oilseed rape $(F=0.14$, $P>0.7)$, but it was very low in the three most isolated grasslands $(745,850$, and $1,000 \mathrm{~m}$ apart from the next oilseed rape field) with $0.6,0.6$, and $0 \%$, respectively. At

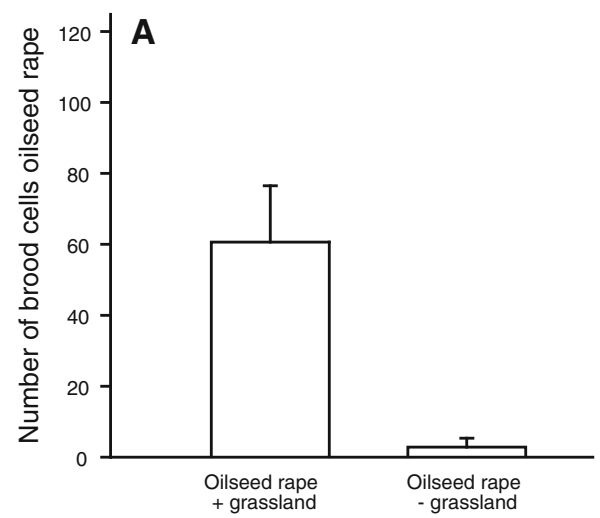

Fig. 1 The mean number $( \pm \mathrm{SE})$ of Red Mason Bee Osmia bicornis brood cells in trap nests in a oilseed rape fields adjacent to grassland (oilseed rape + grassland; $n=17$ ) versus isolated oilseed rape fields (oilseed rape - grassland; $n=17$; model with presence-absence
$655 \mathrm{~m}$ distance from the next oilseed rape field, bees still collected $1.4 \%$ oilseed rape pollen, and at $614 \mathrm{~m}$, the maximum percentage $(8.5 \%)$ for grasslands isolated from oilseed rape was even found.

The number of $O$. bicornis brood cells increased with increasing percentage of oilseed rape pollen in the larval food (Fig. 3; $R^{2}=0.16$, slope $=3.9 ; F_{1,34}=6.5, P=$ $0.015)$. The number of brood cells was not affected by local or landscape-scale availability of alternative food resources (measured as flower cover and number of flowering plant species in the grassland/the adjacent grassland, and the proportion of semi-natural habitats in the landscape) or its interactions with percentage oilseed rape pollen.

\section{Discussion}

We found that mass-flowering oilseed rape fields and seminatural habitats interacted via dispersing and foraging bees, and affected abundances of bees in both habitat types. The probability that the solitary $O$. bicornis colonized trap nests in oilseed rape increased from 12 to $59 \%$ when grassland was adjacent. In grasslands adjacent to oilseed rape fields, the number of brood cells of $O$. bicornis was $55 \%$ higher than in isolated grasslands. The amount of oilseed rape at the landscape scale had no effects. This is in contrast to findings from bumblebees (Westphal et al. 2006; Diekötter et al. 2010; Holzschuh et al. 2011) and from solitary bees (Jauker et al. 2012), where abundances were affected by the amount of oilseed rape in the landscape. However, the results from our study, which was the first study comparing local- and landscape-scale effects of mass-flowering crops in one study setup, suggest that small-scale effects of oilseed rape are much stronger than landscape-scale effectsat least for solitary bees, which perceive their environment at smaller scales than most bumblebees (Westphal et al.

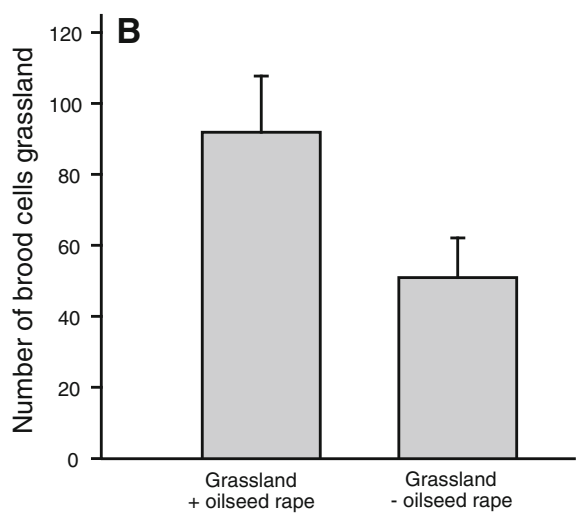

data), b grasslands adjacent to oilseed rape (grassland + oilseed rape; $n=17$ ) versus isolated grasslands (grassland - oilseed rape; $n=16$; model with number of brood cell data) 
2006; Zurbuchen et al. 2010. Holzschuh et al. 2011). And while at the landscape scale large amounts of mass-flowering crops not only enhance bumblebee abundances (Westphal et al. 2006), but can also reduce them (Diekötter et al. 2010, Holzschuh et al. 2011), at the local scale, massflowering crops have so far been found to have only positive effects, namely by attracting bumblebees not only to the crop flowers, but also to wild flowers in the vicinity (Hanley et al. 2011). Our study now shows that the vicinity of oilseed rape also increases the number of brood cells in trap nests. This increase in the number of brood can either result from a higher reproductive output per female and/or from a higher number of females nesting in the trap nest. Although an increase in the number of brood cells per site has been interpreted as an increase of the bees' reproductive output by Jauker et al. (2012), it might also result from an increase in the number of females preferably nesting in the vicinity of oilseed rape. Only a genetic maternity test or permanent observations of the trap nest assigning occupied reed internodes to (uniquely marked) females would enable us to definitely distinguish between higher reproduction and higher colonization in the vicinity of oilseed rape.

We found that the percentage of oilseed rape pollen in the larval food was higher in oilseed rape fields and in grasslands adjacent to oilseed rape compared to isolated grasslands. Our data suggest that the percentage of oilseed

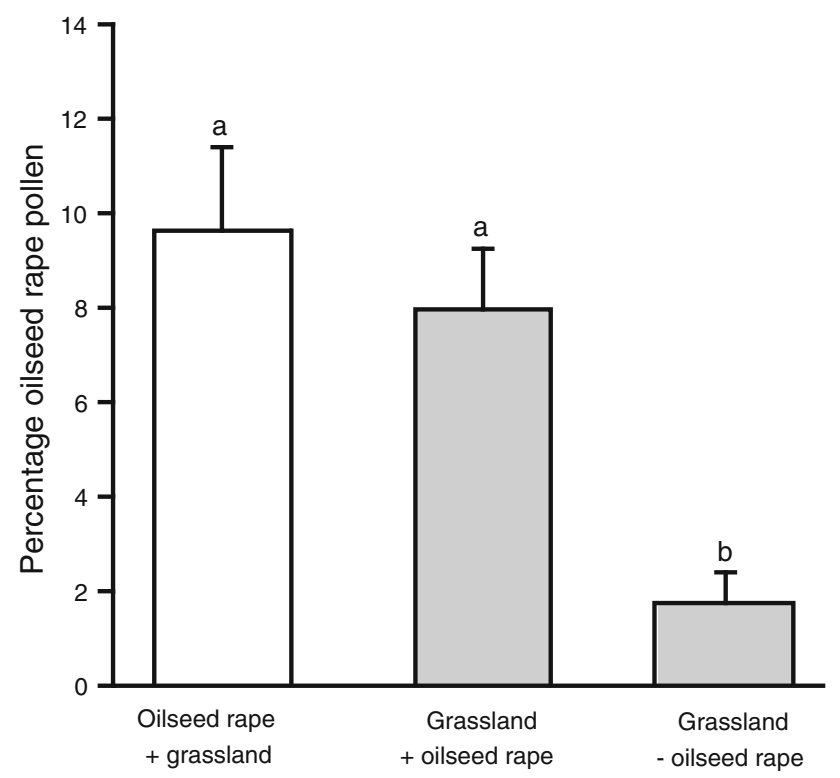

Fig. 2 The mean $( \pm$ SE) percentage oilseed rape pollen in larval food of $O$. bicornis in oilseed rape fields adjacent to grassland (oilseed rape + grassland; $n=17$ ), grasslands adjacent to oilseed rape (grassland + oilseed rape; $n=17$ ) and isolated grasslands (grassland - oilseed rape; $n=16$ ). Data from isolated oilseed rape field were not analyzed, because only 2 of 17 fields had been colonized by $O$. bicornis. Different letters indicate significant differences $(P<0.05$; Tukey contrasts $)$

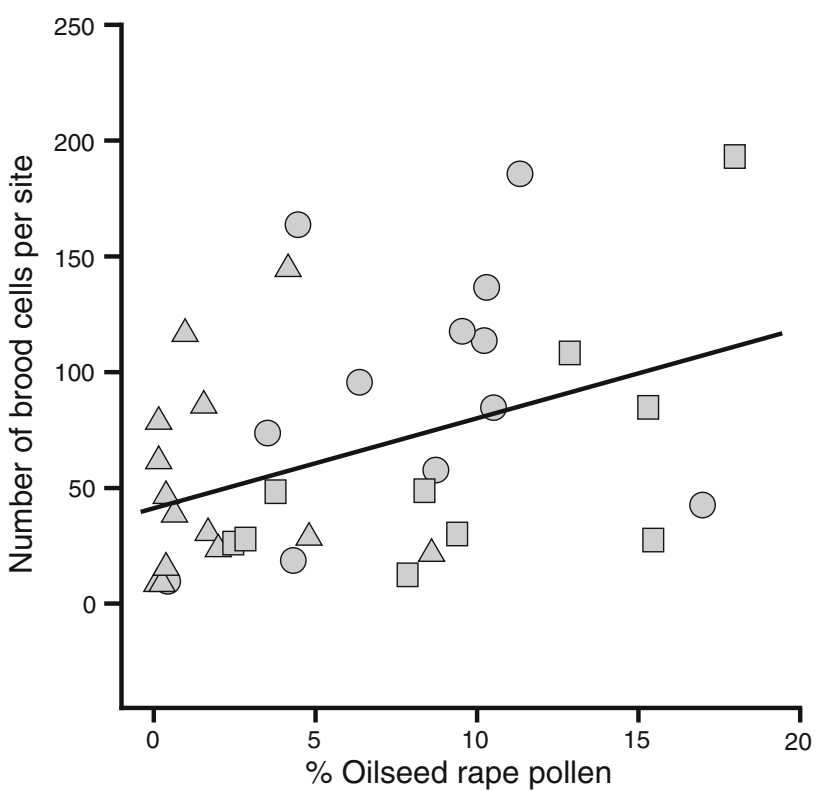

Fig. 3 Relationship between the percentage oilseed rape pollen and the number of $O$. bicornis brood cells in oilseed rape fields adjacent to grassland (squares), grassland adjacent to oilseed rape (rounded crackel), and grassland isolated from oilseed rape (triangles). Data from oilseed rape isolated from grassland were not analyzed because only 2 of 17 fields had been colonized by $O$. bicornis

rape pollen in larval food drastically drop at a distance between 614 and $745 \mathrm{~m}$ from the next oilseed rape. This is in agreement with data from Gathmann and Tscharntke (2002), which suggest maximum foraging distances of about $600 \mathrm{~m}$. In both oilseed rape fields and grasslands, the number of brood cells increased with increasing percentage of oilseed rape pollen in the larval food. A higher percentage of oilseed rape pollen in the larval food may indicate that $O$. bicornis females had to invest less time in collecting the larval food and therefore could produce more brood cells than those females not collecting oilseed rape pollen. Klein et al. (2004) showed that foraging trip durations of a trap-nesting megachilid bee declined and the number of brood cells marginally increased when the blossom cover in the habitat patch increased. Similarly, Zurbuchen et al. (2010) found that the number of brood cells of a specialized bee decreased when the distance to its only food plant increased.

Despite the obvious advantages of collecting oilseed rape pollen when oilseed rape was adjacent, the mean of percentage oilseed rape pollen in the larval food per site never exceeded $20 \%$. Although larvae of O. bicornis raised on pure oilseed rape pollen successfully developed into adults (Konrad et al. 2008), a combination of multiple plant species might be more beneficial (Roulston and Cane 2000). O. bicornis could have been forced to collect pollen from other plants for various reasons: either because the amount of pollen provided by oilseed rape might have 
declined over the flowering period thus making collecting oilseed rape pollen less efficient, or because the composition of amino acid or other nutritional components of oilseed rape was unfavorable (Roulston and Cane 2000; Cook et al. 2003), or because pesticide residues might have repelled bees (Thompson 2003), or, finally, because of toxic oilseed rape pollen compounds (Sedivy et al. 2011). Oilseed rape contains all amino acids essential for honey bees (Weiner et al. 2010); however, the ability to digest pollen of a certain plant species varies strongly even among closely related polylectic bee species and within bee populations (Sedivy et al. 2011). Our study shows that the number of brood cells increased with the percentage of oilseed rape pollen in the larval food up to a percentage of $20 \%$. However, our data do not reveal larval mortality or the reproductive success of the next generation. Further studies are required to assess the effects of oilseed rape pollen on bee fitness in the following generation.

\section{Conclusion}

Our study shows that oilseed rape enhances the abundance of a generalist solitary bee in nearby habitats, and that the number of bee brood cells increased with increasing percentage of oilseed rape pollen in larval food. Our results might be representitive for a large number of bee species, because the majority of European bees are food generalists (Westrich 1989) and might be able to visit oilseed rape. A precondition for the positive effect of oilseed rape is that natural nesting sites (e.g., in semi-natural grassland) are directly adjacent to the oilseed rape field. Thus, an increase of the amount of oilseed rape in the landscape can only be expected to promote wild bees if nesting habitats are already present or if the amount of nesting habitat increases simultaneously with the amount of oilseed rape.

We can only speculate about the longer-term consequences of oilseed rape in the vicinity of semi-natural habitats. Oilseed rape may increase competition among cavity-nesting bee species where nesting sites are the most limiting resource (Steffan-Dewenter and Schiele 2008). This effect could favor early generalist bee species, which could pre-empt nesting cavities for species with more specialized pollen requirements or with later phenology. Furthermore, this effect is likely to carry over into the next season, when a high number of brood cells in grasslands adjacent to oilseed rape in one year will result in a high number of emerging adults in the subsequent year. Thus, competitive pressure on bees that do not benefit from oilseed rape will increase in the subsequent year-regardless of the presence of oilseed rape in the subsequent year. $O$. bicornis is already the most abundant solitary bee in Central Europe (Westrich 1989). Oilseed rape might cause that particularly generalist species that are already dominant might become even more competitive, resulting in negative effects on rare and endangered species in seminatural or natural habitats.

Wild bees that visit oilseed rape fields might enhance farmers' yield, because seed set of oilseed rape depends at least partly on bee pollination (Morandin and Winston 2005; Hoyle et al. 2007). In contrast, wild plants might suffer from a lack of pollination when pollinators prefer foraging in oilseed rape instead of visiting wild plants (Holzschuh et al. 2011). The reproductive success of wild plants flowering simultaneously with oilseed rape and mainly pollinated by generalist bees might also be reduced by deposition of rape pollen on wild flowers. On the other hand, the higher number of emerging adults in the year after oilseed rape flowering might compensate for the lack of pollinators in the previous year and reduce potential pollination limitation of wild plants. Further studies are needed to assess the effects of oilseed rape on competition for pollinators between crops versus wild plants, and on competition for nesting sites between pollinators benefiting from oilseed rape versus non-benefiting pollinators. These studies should take short-term effects (during vs. after mass-flowering period) into account as well as long-term effects via crop rotations that result in annual changes in the distribution of mass-flowering crop fields.

Acknowledgments We thank J. Krauss for help with the study-site selection, S. Schiele for mounting trap nests, L. Shumilovskikh for conducting the pollen analysis and GIS calculations, and the farmers for their participation in the project. A.H. and C.F.D. acknowledge funding from the Helmholtz Association (VH-NG-247) and I.S.D. and A.H. from the European Community's Seventh Framework Programme (FP7/2007-2013) under grant agreement no. 244090, STEP Project (Status and Trends of European Pollinators, www.step-project.net).

Open Access This article is distributed under the terms of the Creative Commons Attribution License which permits any use, distribution, and reproduction in any medium, provided the original author(s) and the source are credited.

\section{References}

Aguilar R, Ashworth L, Galetto L, Aizen MA (2006) Plant reproductive susceptibility to habitat fragmentation: review and synthesis through a meta-analysis. Ecol Lett 9:968-980

Blitzer E, Dormann CF, Holzschuh A, Klein AM, Rand TA, Tscharntke T (2012) Spillover of functionally important organisms between managed and natural habitats. Agric Ecosyst Environ 146:34-43

Carvalheiro LG, Veldtman R, Shenkute AG, Tesfay GB, Pirk CWW, Donaldson JS, Nicolson SW (2011) Natural and within-farmland biodiversity enhances crop productivity. Ecol Lett 14:251-259

Cook S, Awmack C, Murray D, Williams I (2003) Are honey bees' foraging preferences affected by pollen amino acid composition? Ecol Entomol 28:622-627 
Crawley MJ (2007) The R book, 1st edn. Wiley, Chichester

Diekötter T, Kadoya T, Peter F, Wolters V, Jauker F (2010) Oilseed rape crops distort plant-pollinator interactions. J Appl Ecol 47:209-214

Dunning J, Danielson B, Pulliam H (1992) Ecological processes that affect populations in complex landscapes. Oikos 65:169-175

European Commission (2011) Eurostat-Statistics explained: agricultural products. http://epp.eurostat.ec.europa.eu/statistics_ explained/index.php/Agricultural_products. Accessed 24 Oct 2012

Garibaldi LA, Steffan-Dewenter I, Kremen C, Morales JM, Bommarco R, Cunningham SA, Carvalheiro LG, Chacoff NP, Dudenhoeffer JH, Greenleaf SS, Holzschuh A, Isaacs R, Krewenka K, Mandelik Y, Mayfield MM, Morandin LA, Potts SG, Ricketts TH, Szentgyoergyi H, Viana BF, Westphal C, Winfree R, Klein AM (2011) Stability of pollination services decreases with isolation from natural areas despite honey bee visits. Ecol Lett 14:1062-1072

Gathmann A, Tscharntke T (2002) Foraging ranges of solitary bees. J Anim Ecol 71:757-764

Gladbach DJ, Holzschuh A, Scherber C, Thies C, Dormann CF, Tscharntke T (2011) Crop-noncrop spillover: arable fields affect trophic interactions on wild plants in surrounding habitats. Oecologia 166:433-441

Hanley ME, Franco M, Dean CE, Franklin EL, Harris HR, Haynes AG, Rapson SR, Rowse G, Thomas KC, Waterhouse BR, Knight ME (2011) Increased bumblebee abundance along the margins of a mass flowering crop: evidence for pollinator spill-over. Oikos 120:1618-1624

Herberich E, Sikorski J, Hothorn T (2010) A robust procedure for comparing multiple means under heteroscedasticity in unbalanced designs. PLoS One 5:e9788. doi:10.1371/journal.pone.0009788

Holzschuh A, Steffan-Dewenter I, Tscharntke T (2008) Agricultural landscapes with organic crops support higher pollinator diversity. Oikos 117:354-361

Holzschuh A, Steffan-Dewenter I, Tscharntke T (2010) How do landscape composition and configuration, organic farming and fallow strips affect the diversity of bees, wasps and their parasitoids? J Anim Ecol 79:491-500

Holzschuh A, Dormann CF, Tscharntke T, Steffan-Dewenter I (2011) Expansion of mass-flowering crops leads to transient pollinator dilution and reduced wild plant pollination. Proc R Soc Lond B 278:3444-3451

Hoyle M, Hayter K, Cresswell JE (2007) Effect of pollinator abundance on self-fertilization and gene flow: application to GM canola. Ecol Appl 17:2123-2135

Jauker F, Bondarenko B, Becker HC, Steffan-Dewenter I (2012) Pollination efficiency of wild bees and hoverflies provided to oilseed rape. Agric For Entomol14:81-87

Klein AM, Steffan-Dewenter I, Tscharntke T (2004) Foraging trip duration and density of megachilid bees, eumenid wasps and pompilid wasps in tropical agroforestry systems. J Anim Ecol 73:517-525

Klein AM, Vaissiere BE, Cane JH, Steffan-Dewenter I, Cunningham SA, Kremen C, Tscharntke T (2007) Importance of pollinators in changing landscapes for world crops. Proc R Soc Lond B 274:303-313

Konrad R, Ferry N, Gatehouse AMR, Babendreier D (2008) Potential effects of oilseed rape expressing oryzacystatin-1 (OC-1) and of purified insecticidal proteins on larvae of the solitary bee Osmia bicornis. PLoS One 3:e2664. doi:10.1371/journal.pone.0002664
Krebs J, Wilson J, Bradbury R, Siriwardena G (1999) The second silent spring? Nature 400:611-612

Krewenka K, Holzschuh A, Tscharntke T, Dormann CF (2011) Landscape elements as potential barriers and corridors for bees, wasps and parasitoids. Biol Conserv 144:1816-1825

Letourneau DK, Jedlicka JA, Bothwell SG, Moreno CR (2009) Effects of natural enemy biodiversity on the suppression of arthropod herbivores in terrestrial ecosystems. Annu Rev Ecol Evol Syst 40:573-592

Morandin LA, Winston ML (2005) Wild bee abundance and seed production in conventional, organic, and genetically modified canola. Ecol Appl 15:871-881

Potts SG, Biesmeijer JC, Kremen C, Neumann P, Schweiger O, Kunin WE (2010) Global pollinator declines: trends, impacts and drivers. Trends Ecol Evol 25:345-353

R Development Core Team (2011) R: A language and environment for statistical computing, version 2.11.1,. Foundation for statistical computing, Vienna

Rand TA, Louda SA (2006) Spillover of agriculturally subsidized predators as a potential threat to native insect herbivores in fragmented landscapes. Conserv Biol 20:1720-1729

Rand TA, Tylianakis J, Tscharntke T (2006) Spillover edge effects: the dispersal of agriculturally subsidized insect natural enemies into adjacent natural habitats. Ecol Lett 9:603-614

Ricketts TH, Regetz J, Steffan-Dewenter I, Cunningham SA, Kremen C, Bogdanski A, Gemmill-Herren B, Greenleaf SS, Klein AM, Mayfield MM, Morandin L, Ochieng A, Viana BF (2008) Landscape effects on crop pollination services: are there general patterns? Ecol Lett 11:499-515

Roulston T, Cane J (2000) Pollen nutritional content and digestibility for animals. Plant Syst Evol 222:187-209

Sedivy C, Mueller A, Dorn S (2011) Closely related pollen generalist bees differ in their ability to develop on the same pollen diet: evidence for physiological adaptations to digest pollen. Funct Ecol 25:718-725

Steffan-Dewenter I, Schiele S (2008) Do resources or natural enemies drive bee population dynamics in fragmented habitats? Ecology 89:1375-1387

Thompson H (2003) Behavioural effects of pesticides in bees-their potential for use in risk assessment. Ecotoxicology 12:317-330

Tscharntke T, Gathmann A, Steffan-Dewenter I (1998) Bioindication using trap-nesting bees and wasps and their natural enemies: community structure and interactions. J Appl Ecol 35:708-719

Weiner CN, Hilpert A, Werner M, Linsenmair KE, Bluethgen N (2010) Pollen amino acids and flower specialisation in solitary bees. Apidologie 41:476-487

Westphal C, Steffan-Dewenter I, Tscharntke T (2006) Bumblebees experience landscapes at different spatial scales: possible implications for coexistence. Oecologia 149:289-300

Westphal C, Steffan-Dewenter I, Tscharntke T (2009) Mass flowering oilseed rape improves early colony growth but not sexual reproduction of bumblebees. J Appl Ecol 46:187-193

Westrich P (1989) Die Wildbienen Baden-Württembergs, Teil 1: Lebensräume, Verhalten, Ökologie und Schutz. Teil 2: Die Gattungen und Arten, 1st edn. Ulmer, Stuttgart

Zurbuchen A, Landert L, Klaiber J, Müller A,Hein S, Dorn S (2010) Maximum foraging ranges in solitary bees: only fewindividuals have the capability to cover long foraging distances. Biol Conserv 143:669-676 